${ }^{1}$ Absolwentka studiów magisterskich, kierunek Fizjoterapia, Uniwersytet Medyczny w Białymstoku

${ }^{2}$ Instytut Inżynierii Biomedycznej, Politechnika Białostocka

\title{
HIPERMOBILNOŚĆ STAWÓW - PROBLEM SPOLECZNY CZY JEDNOSTKOWY? OCENA CZĘSTOŚCI WYSTĘPOWANIA ZESPOEU HIPERMOBILNOŚCI STAWÓW W LOSOWO WYBRANEJ GRUPIE KOBIET - doniesienia wstepne
}

Joint hypermobility - a social or individual problem? Assessment of the prevalence of hypermobility spectrum disorders in a randomly selected group of women - preliminary reports.

\section{Słowa kluczowe:}

zespół hipermobilności stawów, zespoły bólowe narządu ruchu, test Beigthona.

\section{Key words:}

hypermobility spectrum

disorders, motor organ pains,

Beighton's test.

\section{Streszczenie}

Cel pracy.

Celem pracy jest ocena częstości występowania zespołu hipermobilności stawów w losowo wybranej grupie kobiet. Hipermobilność stawów jest pojęciem wciąż mało znanym $\mathrm{w}$ środowisku medycznym. Tym terminem określamy zwiększony zakres ruchomości w stawach, w odniesieniu do przyjetych norm fizjologicznych. U podłoża występowania hipermobilności leżą zmiany w proporcjach dwóch typów kolagenu, I oraz III. Szerokie występowanie kolagenu w ludzkim organizmie powoduje, że skutki hipermobilności są widoczne zarówno w układzie mięśniowo-szkieletowym, jak i w innych układach i narządach.

\section{Material i metodyka.}

Badanie przeprowadzono na losowo wybranej grupie 60 kobiet w wieku 18-45 lat. Wśród badanych przeprowadzono test Beightona. Uzyskanie co najmniej 4 punktów na 9 możliwych, może świadczyć o występowaniu zespołu hipermobilności stawów.

Wyniki.

Wśród 60 badanych kobiet, 14 uzyskało wynik co najmniej 4 punktów, sugerujący występowanie hipermobilności stawów, co stanowi 23,33\% grupy. Uzyskane wyniki mieściły się w zakresie od 1 do 7 punktów.

\section{Wnioski.}

Przedstawione w niniejszej pracy wyniki badań wskazują na występowanie zespołu hipermobilności stawów u 14 z 60 badanych kobiet, co stanowi ok. 23\% grupy. Chociaż prezentowane wyniki stanowią wstępne rozpoznanie problemu, to można stwierdzić, że częstość występowania zjawiska hipermobilności można uznać za znaczącą.

\section{Abstract}

Purpose.

The aim of the study is to assess the incidence of hypermobility spectrum disorders in a randomly selected group of women. Joint hypermobility is still a term little-known in the medical community. This term defines an increased range of mobility in joints, in relation to the adopted physiological standards. The underlying cause of hypermobility is changes in the proportions of two types of collagen I and III. The wide occurrence of collagen in the human body causes the effects of hypermobility to be visible both in the musculoskeletal system and in other systems and organs.

Material and methods.

The study was conducted on 
a randomly selected group of 60 women aged 18-45 years. Beighton test was conducted among the respondents. Obtaining at least 4 points out of 9 possible may indicate the occurrence of hypermobility spectrum disorders.

\section{Results.}

Of the 60 women studied, 14 scored at least 4 points, suggesting the occurrence of joint hypermobility, which constitutes $23.33 \%$ of the group. The obtained results ranged from 1 to 7 points.

\section{Conclusions.}

The research results presented in this paper indicate the occurrence of hypermobility spectrum disorders in 14 of the 60 women studied, which constitutes approx. $23 \%$ of the group. Although the presented results are a preliminary diagnosis of the problem, it can be concluded that the incidence of hypermobility can be considered significant.

\section{Wprowadzenie}

Hipermobilność stawów jest pojęciem wciąż mało znanym w środowisku medycznym. Tym terminem określamy zwiększony zakres ruchomości w stawach, w odniesieniu do przyjętych norm fizjologicznych. Każdy staw ma określony zakres ruchu, który jest ograniczony przez więzadła i torebki stawowe, tworzące barierę fizjologiczną. Dalszy ruch jest możliwy - jeśli przyłożymy siłę zewnętrzną i biernie „naciagniemy” aparat torebkowowięzadłowy, osiagnniemy bariere anatomiczną stawu. W hipermobilności dochodzi do przekroczenia przeciętnej bariery fizjologicznej stawu bez naruszenia bariery anatomicznej, co wiązałoby się z uszkodzeniem elementów stawowych [1]. Dotyczy to zarówno ruchu wykonywanego czynnie, jak i w sposób bierny. W dostępnej literaturze zjawisko to określane jest jako „wiotkość stawowa, zespół nadruchomości stawów, nadmierna swoboda ruchowa stawów lub zespół łagodnej nadmiernej ruchomości stawów” [2].

U podłoża występowania hipermobilności leżą zmiany w proporcjach dwóch typów kolagenu, I oraz III. Kolagen typu I występuje między innymi w ścięgnach, więzadłach, torebkach stawowych oraz w skórze. Jest odporny na intensywne rozciaganie, jego rola jest zapewnienie sztywności i wytrzymałości tkanki. Włókna kolagenu typu III są obecne w rozciagliwej tkance łaccznej (np. w płucach, naczyniach krwionośnych, ścianach jelit). Jego włókna są cieńsze i bardziej elastyczne. U pacjentów z hipermobilnością zaburzenie proporcji między tymi dwoma typami kolagenu skutkuje rozluźnieniem struktur stawowych zbudowanych $\mathrm{z}$ tkanki łącznej [2].

Szerokie występowanie kolagenu w ludzkim organizmie powoduje, że skutki hipermobilności są widoczne zarówno w układzie mięśniowo-szkieletowym, jak i w innych układach i narządach. Najczęściej spotykanym objawem klinicznym hipermobilnośći jest ból o charakterze przeciążeniowym. Osoby $\mathrm{z}$ nadruchomością skarżą się na dolegliwości bólowe stawów kolanowych, kręgosłupa, ramion, stóp, bioder [3]. Wiąże się to ze zmniejszona tolerancją na obciążenia statyczne, szczególnie podczas dłuższego stania czy siedzenia. Pacjenci hipermobilni są bardziej narażeni na urazy, co z jednej strony może wiązać się z niestabilnością związana ze zwiększonym zakresem ruchu, z drugiej strony zaś zaburzeniami koordynacji i propriocepcji [4]. Warto też wspomnieć o zmianach w obrębie stóp - charakterystyczną cechą osób hipermobilnych jest występowanie płaskostopia (stopa płaska wiotka oraz stopa poprzecznie płaska), czy palucha koślawego [5] (Rycina 1).

Oprócz objawów związanych z układem narządu ruchu nadruchomość daje szereg innych objawów, takich jak: zwiększona rozciągliwość skóry, rozstępy, rozlane blizny, trudne gojenie się ran, niestabilność narządu żucia, obniżenie narządów rodnych, wypadanie odbytu, nietrzymanie moczu, przepukliny, żylaki, zwiększona kruchość naczyń, wypadanie płatka zastawki dwudzielnej [3, 6, 7]. Szczególnie istotnym aspektem są też objawy takie jak depresja, stany lękowe oraz nerwice - niestety osoby hipermobilne postrzegane sa jako hipochondrycy[3, 8, 9]. Częste występowanie dolegliwości bólowych skutkuje też niechęcią do aktywności fizycznej, zwłaszcza jeśli trening nie jest odpowiednio dostosowany do potrzeb pacjenta [8].

Ostatnie lata przyniosły postęp w pracy badawczej nad hipermobilnością. Z powodu rozbieżności, wynikających z używania niejednorodnego nazewnictwa $\mathrm{w}$ literaturze [10], zaproponowano następującą klasyfikację przypadków klinicznych:

1. osoby z hipermobilnością „bezobjawową”, którą możemy potwierdzić pozytywnym wynikiem testu Beightona, ale pacjenci nie odczuwają dolegliwości ze strony układu mięśniowo-szkieletowego,

2. osoby z hipermobilnością, u których spełnione sa kryteria diagnostyczne hipermobilnego typu zespołu EhlersaDanlosa (fEDS),

3. osoby z hipermobilnością, u których nie można potwierdzić diagnozy fEDS, proponuje się określenie: zespół hipermobilności stawów (Hipermobility Spectrum Disorders, HSD).

Wśród pacjentów z rozpoznaniem zespołu hipermobilności stawów (HSD) możemy wyróżnić 4 podstawowe typy:

1. G-HSD (Generalized Hypermobility Spectrum Disorders) - uogólniona postać zespołu hipermobilności stawów, potwierdzona pozytywnym wynikiem testu Beightona. Dodatkowo występują objawy ze strony układu mięśniowoszkieletowego (jeden lub więcej),

2. P-HSD (Peripheral Hypermobility Spectrum Disorders) - hipermobilność 

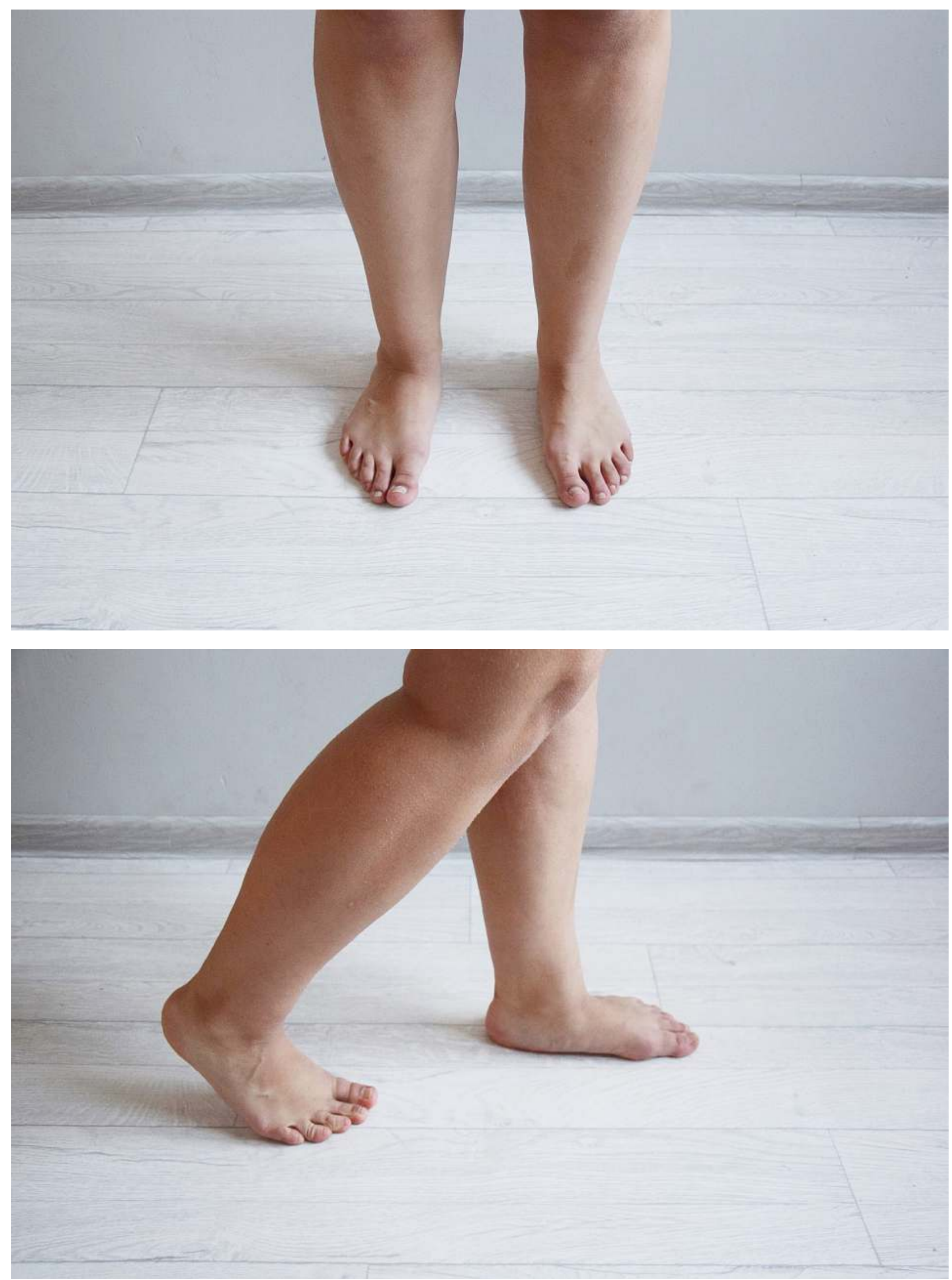

Rycina 1. Charakterystyczne zmiany w ustawieniu stóp u osób hipermobilnych.

www.kif.info.pl 
Ki:

Physiotherapy Review
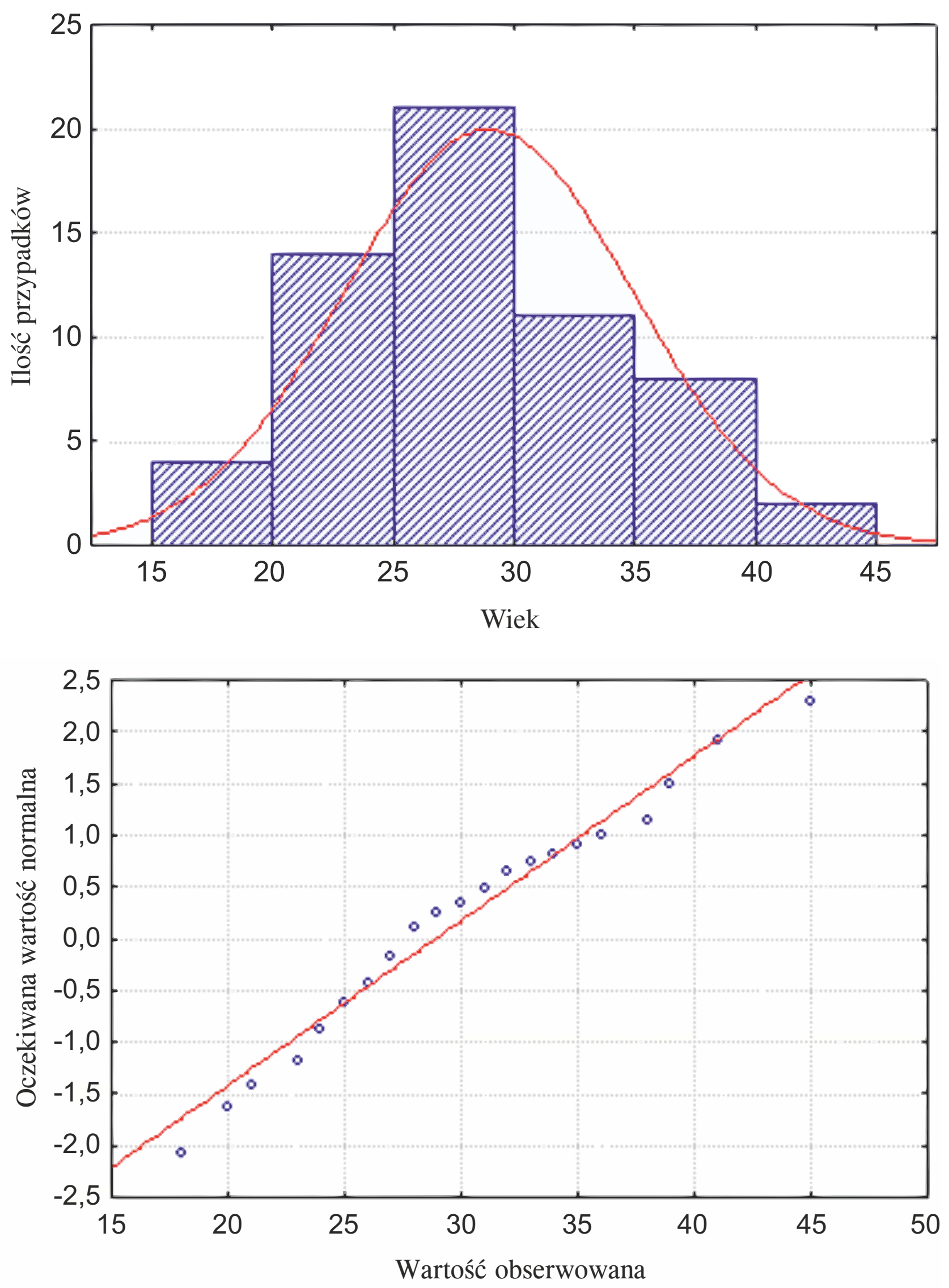

Rycina 2. Analiza wieku osób uczestniczących w badaniu. 
stawów obwodowych, która obejmuje tylko stawy rąk lub/i stóp oraz jeden lub więcej objawów mięśniowoszkieletowych, wynik testu Beightona zazwyczaj jest negatywny,

3. L-HSD (Localized Hypermobility Spectrum Disorders) - hipermobilność ograniczona tylko do jednego stawu z objawami ze strony układu mięśniowoszkieletowego, ale tylko w danej lokalizacji, wynik testu Beightona jest negatywny,

4. H-HSD (Historical Hypermobility Spectrum Disorders) - hipermobilność występująca w przeszłości, wynik testu Begihtona jest negatywny, ale mogą występować objawy mięśniowoszkieletowe (jeden lub więcej).

Z punktu widzenia fizjoterapeutów, do których trafiają pacjenci z opisanymi wyżej dolegliwościami bólowymi, niezwykle ważna jest świadomość, czym jest zespół hipermobilności stawów. Tylko dzięki trafnej diagnozie można odpowiednio określić cel oraz plan terapii z hipermobilnym pacjentem.

\section{Cel pracy}

Celem pracy jest ocena częstości występowania zespołu hipermobilności stawów w losowo wybranej grupie kobiet oraz próba odpowiedzi na pytanie: czy hipermobilność jest problemem powszechnym w naszym społeczeństwie, czy dotyczy tylko pojedynczych przypadków?

\section{Materiał i metodyka}

Badanie przeprowadzono na losowo wybranej grupie 60 kobiet w wieku 18-45 lat (średnia wieku 29lat). Zakwalifikowano uczestniczki, które określały ogólny stan zdrowia jako dobry oraz nie cierpiały na choroby o podłożu reumatologicznym, neurologicznym czy ortopedycznym. Pacjentki otrzymały informację o przebiegu badania oraz podpisały zgodę na udział w badaniu.
Wśród badanych przeprowadzono test Beightona. Idea tego testu polega na ocenie możliwości wykonania przez osobę badaną następujących prób:

1. bierne przeciwstawienie kciuka do dłoniowej strony przedramienia,

2. bierne zgięcie grzbietowe $\mathrm{V}$ palca ręki powyżej $90^{\circ}$,

3. skłon tułowia w przód przy wyprostowanych stawach kolanowych, dłonie położone na podłodze,

4. przeprost w stawie łokciowym powyżej $10^{\circ}$

5. przeprost w stawie kolanowym powyżej $10^{\circ}$.

Wszystkie ruchy, oprócz skłonu tułowia w przód, wykonano oraz oceniono osobno dla prawej oraz lewej kończyny górnej i dolnej. Za każdą pozytywnie wykonaną próbę przyznawano 1 punkt. Uzyskanie co najmniej 4 punktów na 9 możliwych, może świadczyć o występowaniu zespołu hipermobilności stawów $[4,11,12]$.

\section{Wyniki}

Wśród 60 badanych kobiet, 14 uzyskało wynik co najmniej 4 punktów, sugerujący występowanie zespołu hipermobilności stawów, co stanowi 23,33\% grupy. Uzyskane wyniki mieściły się w zakresie od 1 do 7 punktów. Pełne wyniki testu Beightona przedstawia Tabela 1 oraz Rycina 5.

Najczęściej poprawnie wykonywana próbą był skłon w przód, przy prostych stawach kolanowych, który dla 95\% badanych nie sprawił problemu. Znaczne przeprosty (powyżej 10o) w stawach łokciowych wystapiły u 36,67\% grupy (22 osoby), natomiast w stawach kolanowych u 10\% (6 osób). Najrzadziej badający wykonywali bierne ruchy drobnych stawów rak (od 13,33\% do 18,33\% badanej grupy). Wyniki poszczególnych prób testu Beightona przedstawia Tabela 2.

\section{Dyskusja}

Czy hipermobilność jest zjawiskiem występującym powszechnie w dzisiejszym społeczeństwie? W literaturze przedmiotu brak jest odpowiedzi na tak postawione pytanie - w zależności od badanej grupy i metodyki badań, wyniki są dość rozbieżne - od $0,6 \%$ do $31,5 \%$ społeczeństwa może mieć cechy nadruchomości [13]. Badano określone grupy wiekowe, etniczne czy zawodowe. Używano różnorodnych metod, jednak większość z nich sprowadzała się do szczegółowego wywiadu oraz prostych testów funkcjonalnych. Potwierdzono tendencję do spadku częstości występowania z wiekiem [14]. Hipermobilność najczęściej dotyka kobiet oraz mieszkańców Azji i Afryki [14]. Przykładowo Westling i Mattiasson potwierdzili występowanie hipermobilności u 22\% dziewcząt i $13 \%$ chłopców w grupie wiekowej 11-14 lat (gdzie wykonano te badania), Qvindesland i Jonsson u 40,5\% dziewczą i 12,9\% chłopców w wieku 12 lat, natomiast Al Ravi i wsp. - u 38,5\% dorosłych kobiet i $25,4 \%$ dorosłych mężczyzn $[6,15]$. Największą częstotliwość stwierdzono w populacji plemienia Noruba w Nigerii, gdzie nadruchomość potwierdzono u $43 \%$ badanych [16]. W badaniu bliźniąt płci żeńskiej hipermobilność występuje u 19,5\% bliźniąt jednojajowych i $22,1 \%$ bliźniąt dwujajowych, gdzie przy porównaniu zgodności łącznej, czyli potwierdzeniu objawów u obu bliźniąt, otrzymano wynik odpowiednio $60 \%$ i $36 \%$ [14].

Według Stodolnego i Tybinkowskiej nadruchomość dotyczy $12 \%$ badanej przez nich grupy [6]. Znalazło się w niej 50 osób, wybranych w sposób losowy. Grupa została utworzona $\mathrm{z}$ dorosłych (średnia wieku wynosiła 34,8 lat), którzy dotychczas nie leczyli się $\mathrm{z}$ powodu dolegliwości bólowych w obrębie kręgosłupa i narządu ruchu. Łącznie 25 kobiet i 25 mężczyzn zostało poddanych badaniu za pomoca 9-punktowego testu według metodyki proponowanej przez 

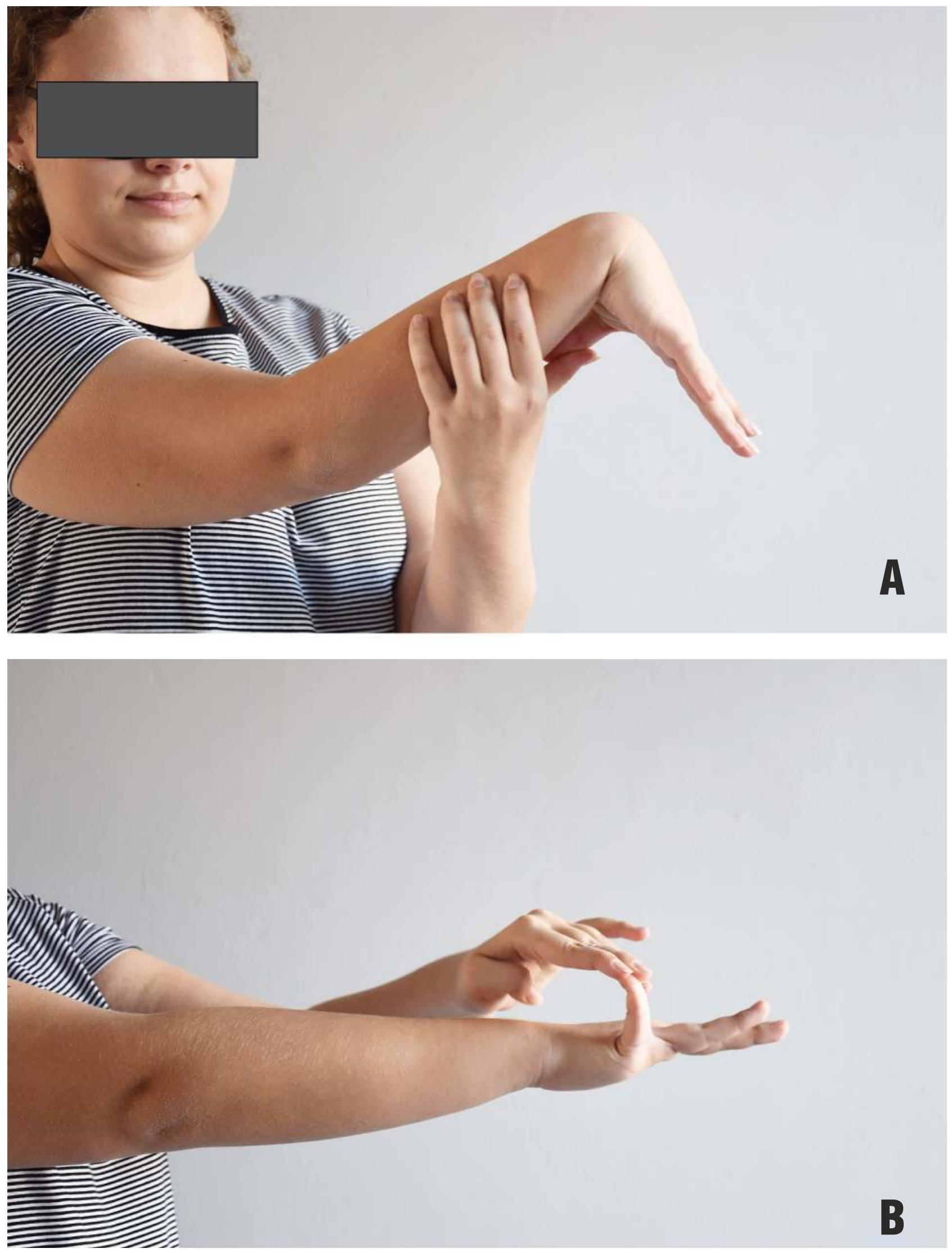

Rycina 3. Test Beightona, próba: A) biernego przeciwstawienia kciuka do dłoniowej strony przedramienia, B) biernego zgięcia grzbietowego V palca powyżej $90^{\circ}$.

www.kif.info.pl 


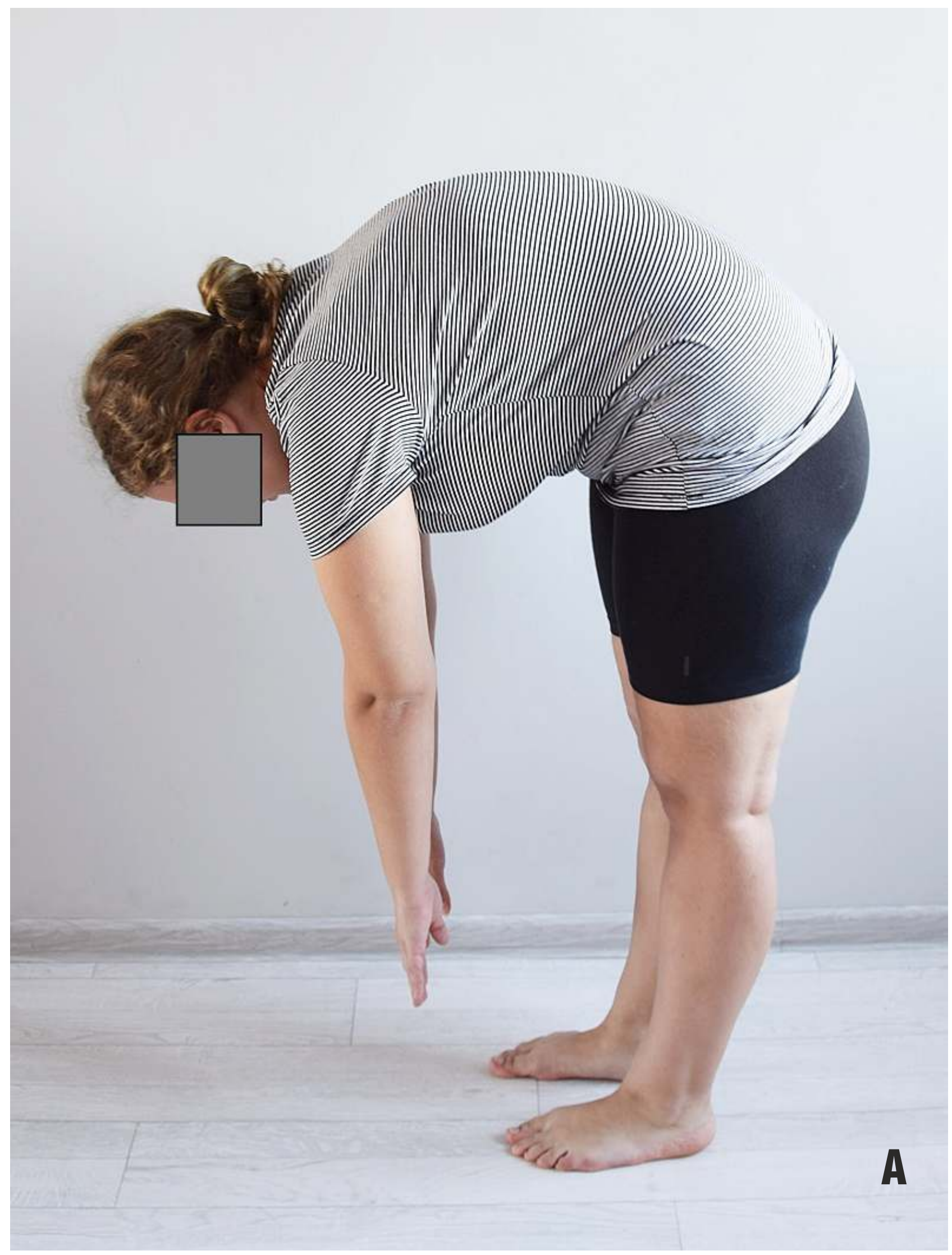

Rycina 4. Test Beightona, próba: A) skłonu tułowia w przód przy wyprostowanych stawach kolanowych 


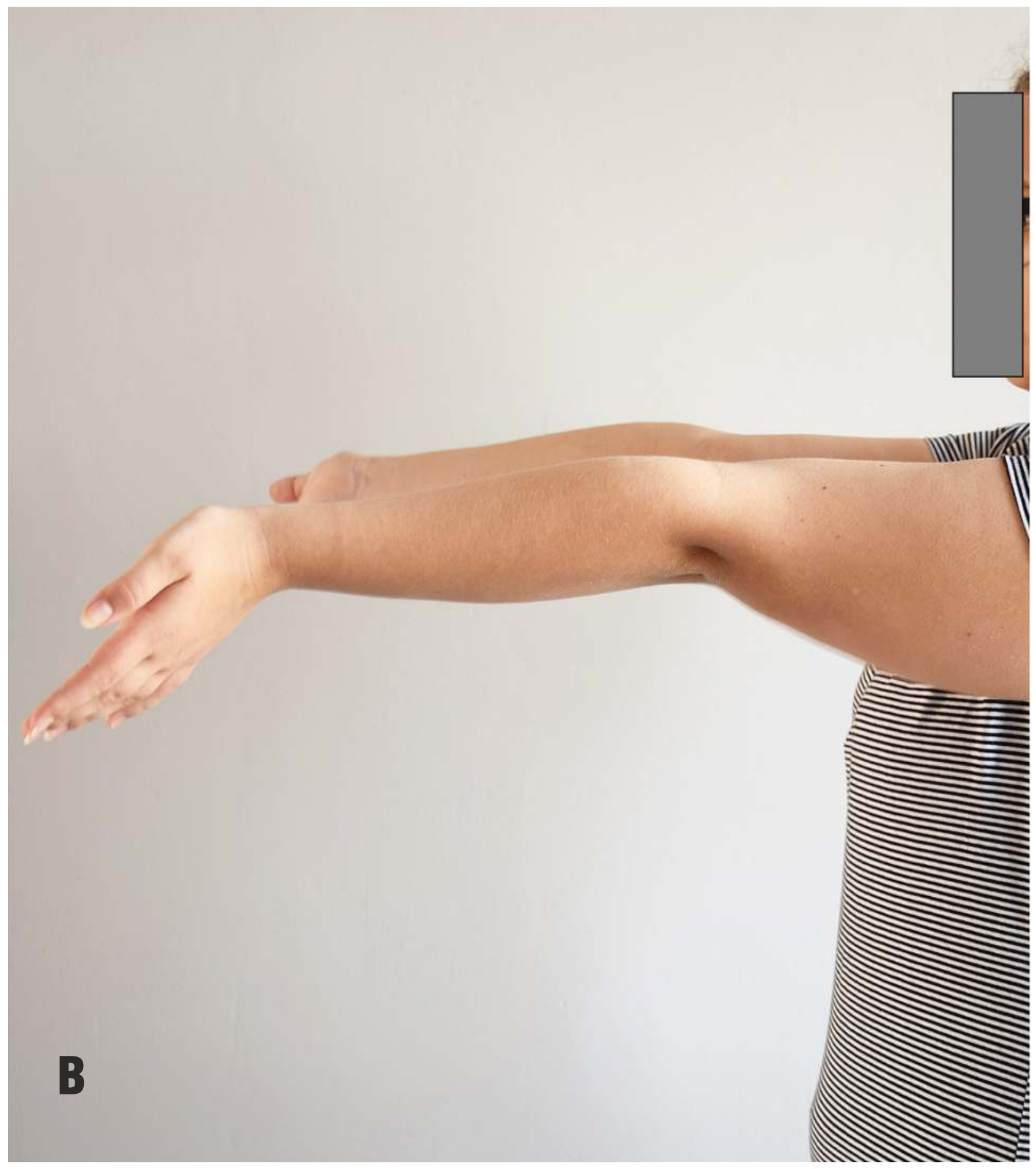

Rycina 4. Test Beightona, próba: B) przeprostu w stawach łokciowych powyżej $10^{\circ}$

Sachsego. Nadruchomość potwierdzono u $16 \%$ kobiet i $8 \%$ mężczyzn. Gdy zawężono grupę badanych do osób z zespołami bólowymi kręgosłupa, wyniki wzrosły do 28\% u kobiet i 19\% u mężczyzn [15]. Autorzy wskazują na coraz częstsze występowanie hipermobilności w polskim społeczeństwie, co może być związane z czynnikami środowiskowymi oraz ubogą w mikroelementy dietą [1, 17].

Z powyższej krótkiej analizy wynika, że badania nad hipermobilnością dają bardzo rozbieżne wyniki. Jest to związane $\mathrm{z}$ różnorodnością metod badania, dlatego wielu autorów wskazuje na potrzebę ujednolicenia kryteriów diagnostycznych [3, 18]. Zastosowany w prezentowanych badaniach test Beightona jest prosty i ogólnodostępny dla wszystkich fizjoterapeutów oraz lekarzy, więc może być używany jako badanie przesiewowe. Jest 


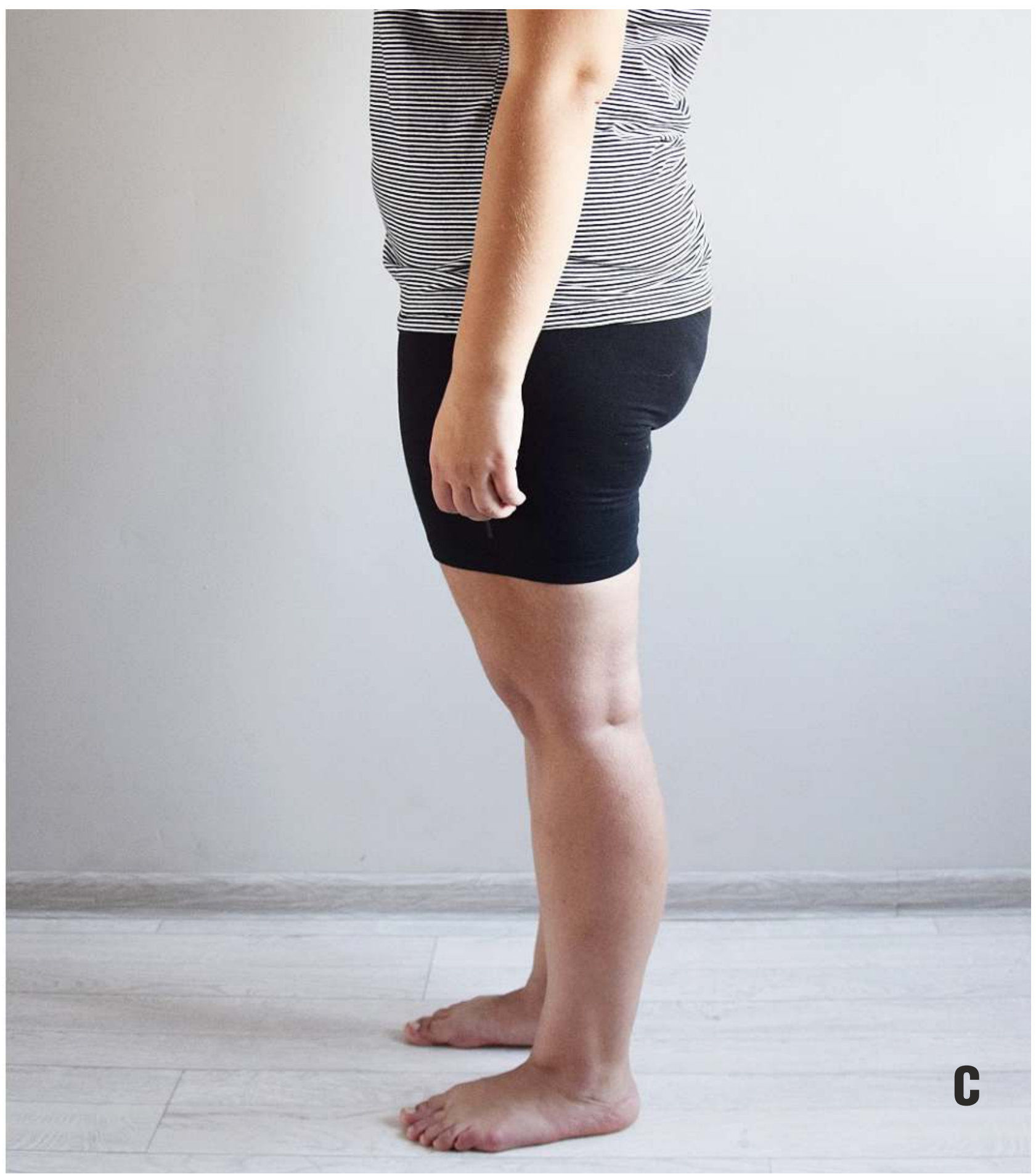

Rycina 4. Test Beightona, próba: C) przeprostu w stawach kolanowych powyżej $\mathbf{1 0}^{\circ}$.

też najczęściej cytowanym kryterium diagnostycznym, spotykanym w literaturze [12]. Nie uwzględnia jednak objawów spoza układu mięśniowo-szkieletowego [9]. Dlatego też opracowano kryteria Brighton, które obejmują kryteria duże (wynik testu Beightona 4 lub więcej oraz bóle w obrębie czterech lub większej ilości stawów przez okres dłuższy niż 3 miesiące) oraz kryteria małe (np. zwichnięcia lub podwichnięcia stawów, reumatyzm tkanek miękkich, objawy skórne, objawy oczne, sylwetka marfanoidalna, żylaki lub przepukliny, wypadanie narządu rodnego lub odbytu) [3, 12]. Test Beightona bada też selektywne zakresy ruchu poszczególnych stawów, pomijając ruchomość np. stawu barkowego lub inne, oprócz zgięcia, ruchy kręgosłupa. Uwzględniono je w skali Bulbena oraz skali Sachsego w modyfikacji Kapandij'ego [2, 3]. Sa to jednak testy, 
Tabela 1. Wyniki testu Beightona.

\begin{tabular}{|c|c|c|}
\hline Wynik testu Beightona & Liczba przypadków & \% wszystkich przypadków \\
\hline 1 punkt & 25 & 41,67 \\
\hline 2 punkty & 4 & 6,67 \\
\hline 3 punkty & 17 & 28,33 \\
\hline 4 punkty & 3 & 16,67 \\
\hline 5 punktów & 10 & 0 \\
\hline 6 punktów & 0 & 1,67 \\
\hline 7 punktów & 1 & 0 \\
\hline 8 punktów & 0 & 0 \\
\hline 9 punktów & 0 & \\
\hline
\end{tabular}

Rycina 5. Wyniki testu Beightona.

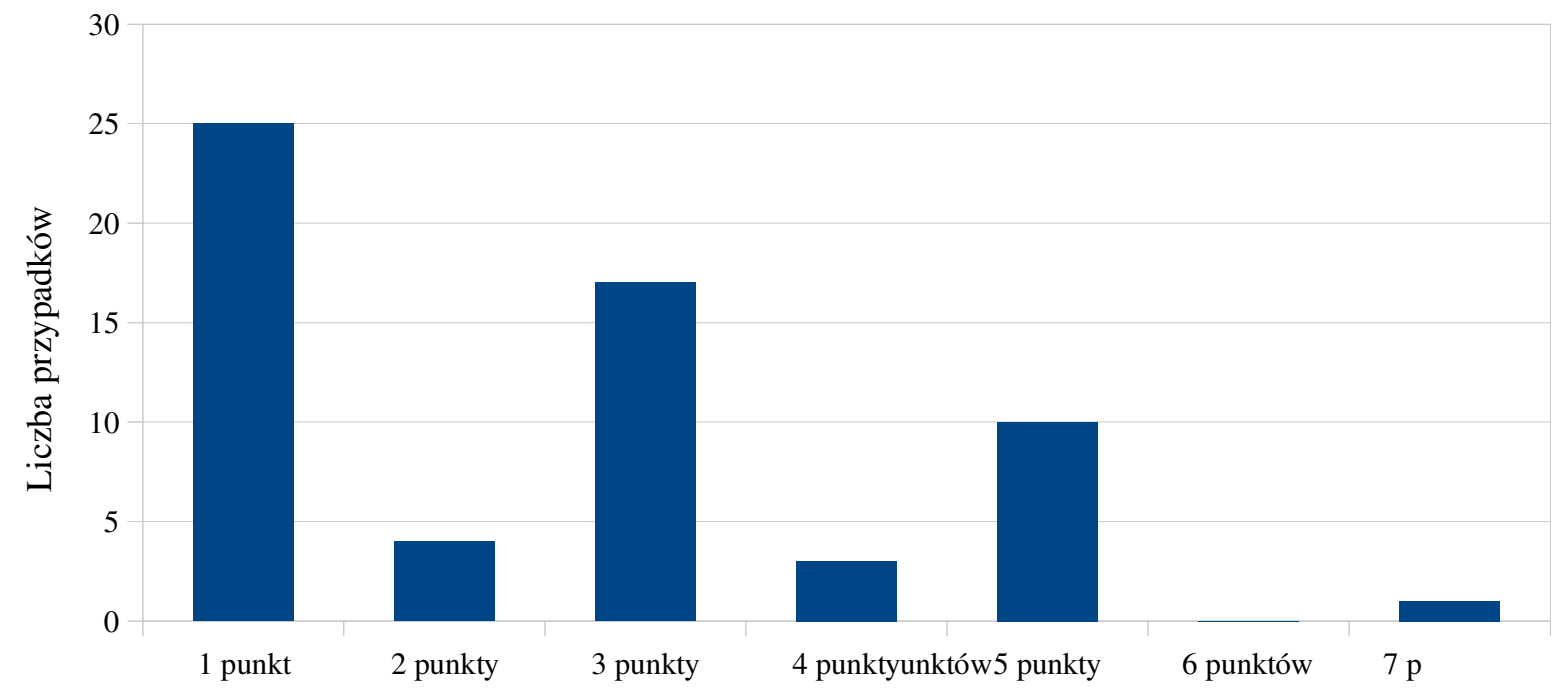

Wynik testu Beightona

które zdecydowanie wydłużają badanie oraz są trudniejsze do przeprowadzenia jako test przesiewowy.

Nie ulega wạtpliwości, że fizjoterapeuci powinni mieć świadomość występowania zespołu hipermobilności stawów. To do tej grupy zawodowej najcześciej trafiaja pacjenci z dolegliwościami bólowymi. Znajomość przyczyn i objawów zwiększonej ruchomości stawów, pozwala zaplanować skuteczną terapię. Prace $\mathrm{z}$ nadruchomym pacjentem należy zacząc od wyeliminowania wszystkich ćwiczeń, które zwiększają zakres ruchu (np. stretching, joga, gimnastyka artystyczna), zastępując je treningiem zwiększającym stabilizację stawową $[1,16]$. Ważna jest poprawa propriocepcji, koordynacji oraz sily mięśni [3, 12]. Udowodniono pozytywne efekty treningu o charakterze silowym oraz wytrzymałościowym [8]. Przydatne są techniki PNF, ćwiczenia $\mathrm{z}$ taśmami TheraBand czy poduszkami sensomotorycznymi [5]. Warto też zwrócić uwagę pacjenta na codzienne funkcjonowanie: a) unikanie przeciążeń statycznych, zarówno w pracy, jak i podczas czynności dnia codziennego;

b) kontrola wagi, by nie dopuszczać do dodatkowego obciążenia dla stawów;

c) unikanie nadmiernego przeciążenia mięśni - nie spełniają wtedy funkcji bariery ochronnej dla stawów, dodatkowo bezpośrednio obciążając aparat więzadłowotorebkowy $[1,5,16]$. 
Tabela 2. Wyniki poszczególnych prób testu Beightona.

\begin{tabular}{|l|c|c|}
\hline \multicolumn{1}{|c|}{ Próba } & $\begin{array}{c}\text { Wynik ujemny } \\
\text { (liczba przypadków) }\end{array}$ & $\begin{array}{c}\text { Wynik dodatni } \\
\text { (liczba przypadków) }\end{array}$ \\
\hline Bierne przeciwstawienie kciuka - prawa ręka & 52 & 11 \\
\hline Bierne przeciwstawienie kciuka - lewa ręka & 49 & 10 \\
\hline Bierne zgięcie grzbietowe V palca - prawa ręka & 50 & 10 \\
\hline Bierne zgięcie grzbietowe V palca - lewa ręka & 50 & 57 \\
\hline Skłon tułowia w przód & 3 & 22 \\
\hline Przeprost w stawie łokciowym - prawa ręka & 38 & 22 \\
\hline Przeprost w stawie łokciowym - lewa ręka & 38 & 6 \\
\hline Przeprost w stawie kolanowym - prawa noga & 54 & 6 \\
\hline Przeprost w stawie kolanowym - lewa noga & 54 & 2 \\
\hline
\end{tabular}

\section{Wnioski}

Przedstawione w niniejszej pracy wyniki badań wskazują na występowanie zespołu hipermobilności stawów u 14 z 60 badanych kobiet, co stanowi ok. $23 \%$ grupy. Chociaż prezentowane wyniki stanowią wstępne rozpoznanie problemu, to można stwierdzić, że częstość występowania zjawiska hipermobilności można uznać za znaczacac. Ponadto przyjęta w pracy metodyka badań wskazuje na to, że test Beigthona może być stosowany jako badanie przesiewowe, które należy uzupełnić o dodatkowe kryteria diagnostyczne (np. kryteria Brighton). Ze względu na częstotliwość występowania, fizjoterapeuci powinni wiedzieć czym jest hipermobilność, umieć postawić trafną diagnozę oraz pracować z pacjentem hipermobilnym. Pozwoli to na podniesienie efektywności prowadzonej terapii oraz ułatwi pacjentom codzienne funkcjonowanie, bez uciążliwych dolegliwości bólowych.

\section{Piśmiennictwo}

1. Stodolny J.: Choroba przeciążeniowa kręgosłupa. Wydawnictwo ZL Natura, Kielce 2000.

2. Stodolna J., Stodolny J., Marczyński W.: Hipermobilność konstytucjonalna jako przyczyna zespołów bólowych narządu ruchu. Kwart. Ortoped., 2006, 2, 100104.

3. Kopff B., Raczkowski J.: Zespół hipermobilności stawów - rzadko rozpoznawana patologia w obrębie narządu ruchu. Kwart. Ortoped., 2011, 2, 80-92.

4. Dziak A.: Dysfunkcje stawów kończyn. Acta Clin., 2002, 2(2), 129-136.

5. Mirska A., Kalinowska A., Topór E., Okluczyk K., Kułak W.: Łagodny zespół hipermobilności stawów (BHJS). Neurologia dziecięca, 2011, 20, 135-140.

6. Stodolny J., Tybinkowska A.: Częstotliwość występowania nadruchomości konstytucjonalnej stawów w losowo wybranej grupie osób. Postępy Rehabil., 1997, 11(2), 73-77.

7. Russek L.: Examination and treatment of a patient with hypermobility syndrome. Phys. Ther., 2000, 80(4), 386-398.

8. Engelbert R.H., Juul-Kristensen B., Pacey V., de Wandele I., Smeenk S., Woinarosky N., Sabo S., Scheper M.C., Russek L., Simmonds J.V.: The evidence-based rationale for physical therapy treatment of children, adolescents, and adults diagnosed with joint hypermobility syndrome/hypermobile Ehlers Danlos syndrome. Am J Med Genet C Semin Med Genet. 2017 Mar; 175(1): 158-167.

9. Bravo J., Wolff C.: Clinical study of hereditary disorders of connective tissues in a Chilean population. Arthritis Rheum., 2006, 54(2), 515-523.

10. Castori M., Tinkle B., Levy H., Grahame R., Malfait F., Hakim A.: A Framework for the Classification of Joint Hypermobility and Related Conditions. Am J Med Genet C Semin Med Genet. 2017 Mar; 175(1): 148-157.

11. Juul-Kristensen B., Rongind H., Jensen D., Removig L.: Inter-examiner reproducibility of test and criteria for generalized joint hypermobility and benign joint hypermobility syndrome. Rheumatology 2007. 46, 1835-1841.

12. Simpson M.: Bengin joint hypermobility syndrome: evaluation, diagnosis, and management. J. Am. Osteopath. Assoc., 2006, 106(9), 531-536.

13. Zweers M., Hakim A., Grahame R., Schalkwijk J.: Joint hypermobility syndrome. Arthritis Rheum., 2004, 50(9), 2742-2749.

14. Hakim A., Cherkas L., Grahame R., Spector T., MacGregor A.: The genetic 
Epidemiology od joint hypermobility. Arthritis Rheum., 2004, 50(8), 26402644.

15. Qvindesland A., Jonsson H.: Articular hypermobility in Icelandic 12-years-olds. Rheumatology, 1999, 38, 1014-1016.

16. Juul-Kristensen B., Schmedling K., Rombaut
L., Lund H., Engelbert R.H.: Measurement properties of clinical assessment methods for classifying generalized joint hypermobility-A systematic review. Am J Med Genet C Semin Med Genet. 2017 Mar; 175(1): 116-147.

17. Stodolny J.: Częstość występowania nadruchomości konstytucjonalnej stawów wśród chorych z zespołami bólowymi kręgosłupa. Postępy Rehabil., 1997, 11(2), 79-85.

18. Skiwot M., Śliwiński G., Milanese S., Śliwiński Z:: Hypermobility of joints in dancers. PloS One, 2019, 14(2), 1-13. 